\title{
Platelets in Coronavirus Disease 2019
}

\author{
Julie Brogaard Larsen, MD, $\mathrm{PhD}^{1} \quad$ Leonardo Pasalic, $\mathrm{MB}$ \\ ${ }^{1}$ Thrombosis and Haemostasis Research Unit, Department of Clinical \\ Biochemistry, Aarhus University Hospital, Aarhus, Denmark \\ 2 Sydney Centres for Thrombosis and Haemostasis, Sydney, Australia \\ ${ }^{3}$ Department of Haematology, Institute of Clinical Pathology and \\ Medical Research, Westmead Hospital, NSW Health Pathology, \\ Sydney, Australia \\ ${ }^{4}$ Department of Clinical Medicine, Aarhus University, Aarhus, \\ Denmark
}

Semin Thromb Hemost 2020;46:823-825.

In December 2019, the first cases of infection with a novel human microorganism, now officially defined as severe acute respiratory syndrome coronavirus 2 (SARS-CoV-2), were reported in Wuhan, China. ${ }^{1}$ On April 1, 2020, as we write, more than 800,000 cases of the novel coronavirus disease 2019 (COVID-19) have been reported worldwide, with more than 40,000 COVID-19-related deaths. ${ }^{2}$

Studies have reported disturbed coagulation in COVID-19 patients, including prolonged prothrombin time, ${ }^{3,4}$ decreased antithrombin, ${ }^{3}$ and increased fibrin degradation products such as D-dimer. ${ }^{3-7}$ This implies increased risk of thromboembolic disease, as well as bleeding and, for the most serious cases, development of disseminated intravascular coagulation (DIC), which, in one case series, was reported in as many as $71 \%$ of nonsurvivors of COVID- $19 .^{5}$

This commentary explores the potential role of platelets in COVID-19, including the link between thrombocytopenia and disease severity and the considerations for the potential role for platelet function and/or platelet activation testing in COVID-19 patients.

\section{Platelet Count and Disease Severity in COVID-19}

Thrombocytopenia is reported in 5 to $40 \%$,6,8,9 of COVID-19 patients and appears to be associated with more severe disease. A meta-analysis by Lippi et $\mathrm{al}^{10}$ including nine studies with more than 1,700 COVID-19 patients in total, reported a significant association between thrombocytopenia at admission and severe disease. Platelet counts were significantly lower in severely ill patients (weighted mean difference: $-31.5 \times 10^{9} / \mathrm{L}$ ) and were associated with increased mortality in a subgroup analysis. This is supported by additional studies ${ }^{11-13}$; Mo et al reported lower platelet counts in patients with refractory disease $(n=85)$, defined as a lack of clinical and radiological
Address for correspondence Anne-Mette Hvas, MD, PhD, Thrombosis and Haemostasis Research Unit, Department of Clinical Biochemistry, Aarhus University Hospital, Palle Juul-Jensens Boulevard 99, DK-8200 Aarhus, Denmark (e-mail: am.hvas@dadlnet.dk). remission after 10 days, than in patients with remission after 10 days $(n=70)$ (mean with interquartile range [IQR]: 159 [119-202] vs. $\left.179[146-219] \times 10^{9} / \mathrm{L}\right) .{ }^{11}$ In a study of 107 patients, Wang et al reported lower platelet count in nonsurvivors $(n=19)$ than survivors (mean with IQR: 122 [83-178] vs. 178 [139-207] $\left.\times 10^{9} / \mathrm{L} ; p<0.01\right) .^{12}$ It should be noted that the study by Wang et al is still in the process of completing peer review. Finally, a study by Tang et al including 449 patients found platelet count to be negatively correlated with 28-day mortality in a multivariate analysis. ${ }^{13}$

However, the majority of even severely ill COVID-19 patients exhibit only mild thrombocytopenia. One case series $(n=62)$ reported that only $5 \%$ of patients had platelets counts $<100 \times 10^{9} / \mathrm{L}^{14}$ and in 69 patients from Singapore, no patients had platelet counts $<100 \times 10^{9} / \mathrm{L}$ at admission. ${ }^{9}$ In studies reporting on platelet count in COVID-19, mean platelet counts ranged from $\sim 160$ to $215 \times 10^{9} / \mathrm{L}$ in COVID19 patients in general ${ }^{4,6-8,11,12,15-18}$ to 120 to $200 \times 10^{9} / \mathrm{L}$ in severely ill patients. $4,6,7,11,12,15-17,19,20$ Tang et al reported on the association between coagulopathy and mortality in 183 COVID-19 patients. ${ }^{5}$ Of the 21 patients who did not survive, 12 (57\%) had platelet counts $<100 \times 10^{9} / \mathrm{L}$.

Based on these data, it appears that while mild thrombocytopenia is a common finding in COVID-19 patients, a platelet count of $<100 \times 10^{9} / \mathrm{L}$ seems rare and should be interpreted as an indicator of present or developing coagulopathy. This could help identify patients who could benefit from thromboprophylaxis. ${ }^{13}$

Interestingly, $\mathrm{Qu}$ et al demonstrated an association between high platelet counts and poor prognosis. ${ }^{21}$ The authors found that severely ill COVID-19 patients exhibited higher peak platelet counts than their nonseverely ill peers during hospital admission and that the platelet-to-lymphocyte ratio during platelet peak was markedly higher in severely ill patients. However, the study included 30 patients in total, with published online April 30, 2020
Issue Theme Maintaining Hemostasis and Preventing Thrombosis in COVID-19 -Part I; Guest Editors: Emmanuel J. Favaloro, PhD, FFSc (RCPA), and Giuseppi Lippi, MD.
Copyright $\odot 2020$ by Thieme Medical Publishers, Inc., 333 Seventh Avenue, New York, NY 10001, USA. Tel: +1(212) 760-0888.
DOI https://doi.org/ 10.1055/s-0040-1710006. ISSN 0094-6176. 
only 3 with severe disease. Thus, these findings should be replicated in other cohorts before the platelet-to-lymphocyte ratio can be better investigated as a prognostic factor. Furthermore, low lymphocyte counts have consistently been found associated with worse prognosis, ${ }^{4,6}$ and this may be the explanation for the findings described by $\mathrm{Qu}$ et al, more than the high platelet counts per se.

\section{Mechanisms behind Thrombocytopenia in COVID-19: A Role for Platelet Activation?}

Platelets are known to interact directly with several different types of virus through surface integrins, P-selectin, and toll-like receptors, as recently reviewed in detail in this journal by Page and Pretorius. ${ }^{22}$ Regarding interactions between SARS-CoV-2 and platelets, however, current knowledge is sparse. Some lessons may be learned from the SARS-CoV and MERS-CoV (Middle East respiratory syndrome coronavirus) outbreaks in 2002 to 2003 and 2012, where similar findings have been described of thrombocytopenia, predominantly mild, in 30 to $50 \%$ of patients. ${ }^{23-26}$

Mechanisms behind thrombocytopenia in the 2003 SARS-CoV infection have been reviewed by Yang et al. ${ }^{27}$ These may include both a direct influence of the virus on hematopoiesis and megakaryocyte maturing, and an increased platelet adhesion and activation and subsequent platelet consumption in the microcirculation of damaged lung tissue. ${ }^{27}$ Platelet activation in the pulmonary microcirculation could not only contribute to the procoagulant activity described in COVID-19 patients but also aggravate damage to the lung parenchyma and contribute to the respiratory distress and frequent need for mechanical ventilation, which is a hallmark of severe COVID-19. Finally, hyperinflammation appears to be a prominent feature of severe COVID-19, as increased serum levels of ferritin, interleukin-6, and other proinflammatory cytokines have been reported and are linked to worse prognosis in COVID19. 4,7,28,29 This could also contribute to platelet activation in COVID-19. ${ }^{30}$

These data open interesting perspectives for the role of platelet activation and for possible benefits of antiplatelet agents in COVID-19. However, these questions should be explored in future research since, to the best of our knowledge, no study has yet reported on platelet activation in COVID-19 patients.

\section{Conclusion}

To conclude, mild thrombocytopenia is a common finding in COVID-19, and thrombocytopenia is linked with more severe disease and mortality. Platelet counts $<100 \times 10^{9} / \mathrm{L}$ should lead the clinician to suspect the development of complications in the COVID-19 patient, for example, DIC.

Our current knowledge of other human coronaviruses suggests that ongoing platelet activation in pulmonary and other tissues could be present in COVID-19 and could hence contribute to increased procoagulant activity observed in COVID-19. However, to the best of our knowledge, platelet function testing has not been performed in COVID-19 patients so far. This is a focal point for future research to increase our understanding of the pathophysiology of COVID-19 and explore possible treatment targets.

\section{Conflicts of Interest}

Dr. Hvas reports grants from CSL Behring and other fees from CSL Behring, Boehringer Ingelheim, and Bayer, outside the submitted work.

\section{References}

1 Zhu N, Zhang D, Wang W, et al; China Novel Coronavirus Investigating and Research Team. A novel coronavirus from patients with pneumonia in China, 2019. N Engl J Med 2020; 382(08):727-733

2 John's Hopkins University. Coronavirus COVID-19 Global Cases by the Center for Systems Science and Engineering (CSSE) at Johns Hopkins University (JHU). Available at: https://coronavirus.jhu.edu/map.html. Accessed April 1, 2020

3 Han H, Yang L, Liu R, et al. Prominent changes in blood coagulation of patients with SARS-CoV-2 infection. Clin Chem Lab Med 2020 (e-pub ahead of print) . Doi: 10.1515/cclm-2020-0188

4 Zhou F, Yu T, Du R, et al. Clinical course and risk factors for mortality of adult inpatients with COVID-19 in Wuhan, China: a retrospective cohort study. Lancet 2020;395(10229):1054-1062

5 Tang N, Li D, Wang X, Sun Z. Abnormal coagulation parameters are associated with poor prognosis in patients with novel coronavirus pneumonia. J Thromb Haemost 2020;18(04):844-847

6 Guan WJ, Ni ZY, Hu Y, et al; China Medical Treatment Expert Group for Covid-19. Clinical characteristics of coronavirus disease 2019 in China. N Engl J Med 2020 (e-pub ahead of print) . Doi: 10.1056/NEJMoa2002032

7 Huang C, Wang Y, Li X, et al. Clinical features of patients infected with 2019 novel coronavirus in Wuhan, China. Lancet 2020;395 (10223):497-506

8 Chen N, Zhou M, Dong X, et al. Epidemiological and clinical characteristics of 99 cases of 2019 novel coronavirus pneumonia in Wuhan, China: a descriptive study. Lancet 2020;395(10223):507-513

9 Fan BE, Chong VCL, Chan SSW, et al. Hematologic parameters in patients with COVID-19 infection. Am J Hematol 2020

10 Lippi G, Plebani M, Henry BM. Thrombocytopenia is associated with severe coronavirus disease 2019 (COVID-19) infections: a meta-analysis. Clin Chim Acta 2020;506:145-148

11 Mo P, Xing Y, Xiao Y, et al. Clinical characteristics of refractory COVID-19 pneumonia in Wuhan, China. Clin Infect Dis 2020 (epub ahead of print) . Doi: 10.1093/cid/ciaa270

12 Wang D, Yin Y, Hu C, et al. Clinical course and outcome of novel coronavirus COVID-19 infection in 107 patients discharged from the Wuhan hospital. Crit Care 2020 (e-pub ahead of print) . Doi: 10.21203/rs.3.rs-16485/v1

13 Tang N, Bai H, Chen X, Gong J, Li D, Sun Z. Anticoagulant treatment is associated with decreased mortality in severe coronavirus disease 2019 patients with coagulopathy. J Thromb Haemost 2020 (e-pub ahead of print) . Doi: $10.1111 /$ jth.14817

$14 \mathrm{Xu}$ XW, Wu XX, Jiang XG, et al. Clinical findings in a group of patients infected with the 2019 novel coronavirus (SARS-Cov-2) outside of Wuhan, China: retrospective case series. BMJ 2020;368:m606

15 Liu W, Tao ZW, Lei W, et al. Analysis of factors associated with disease outcomes in hospitalized patients with 2019 novel coronavirus disease. Chin Med J (Engl) 2020 (e-pub ahead of print) . Doi: 10.1097/CM9.0000000000000775

16 Young BE, Ong SWX, Kalimuddin S, et al; Singapore 2019 Novel Coronavirus Outbreak Research Team. Epidemiologic features and clinical course of patients infected with SARS-CoV-2 in Singapore. JAMA 2020 (e-pub ahead of print) . Doi: 10.1001/jama.2020.3204 
17 Yang X, Yu Y, Xu J, et al. Clinical course and outcomes of critically ill patients with SARS-CoV-2 pneumonia in Wuhan, China: a singlecentered, retrospective, observational study. Lancet Respir Med 2020 (e-pub ahead of print) . Doi: 10.1016/S2213-2600(20)30079-5

18 Arentz M, Yim E, Klaff L, et al. Characteristics and outcomes of 21 critically ill patients With COVID-19 in Washington state. JAMA 2020 (e-pub ahead of print) . Doi: 10.1001/jama.2020.4326

19 Ruan Q, Yang K, Wang W, Jiang L, Song J. Clinical predictors of mortality due to COVID-19 based on an analysis of data of 150 patients from Wuhan, China. Intensive Care Med 2020 (e-pub ahead of print) . Doi: 10.1007/s00134-020-05991-x

20 Bhatraju PK, Ghassemieh BJ, Nichols M, et al. COVID-19 in critically ill patients in the Seattle region - case series. N Engl J Med 2020 (e-pub ahead of print). Doi: 10.1056/NEJMoa2004500

$21 \mathrm{Qu} \mathrm{R}$, Ling Y, Zhang YH, et al. Platelet-to-lymphocyte ratio is associated with prognosis in patients with coronavirus disease- 19 . J Med Virol 2020 (e-pub ahead of print) . Doi: 10.1002/jmv.25767

22 Page MJ, Pretorius E. A champion of host defense: a generic largescale cause for platelet dysfunction and depletion in infection. Semin Thromb Hemost 2020;46(03):302-319

23 Choi KW, Chau TN, Tsang O, et al; Princess Margaret Hospital SARS Study Group. Outcomes and prognostic factors in 267 patients with severe acute respiratory syndrome in Hong Kong. Ann Intern Med 2003;139(09):715-723
24 Wong RS, Wu A, To KF, et al. Haematological manifestations in patients with severe acute respiratory syndrome: retrospective analysis. BMJ 2003;326(7403):1358-1362

25 Saad M, Omrani AS, Baig K, et al. Clinical aspects and outcomes of 70 patients with Middle East respiratory syndrome coronavirus infection: a single-center experience in Saudi Arabia. Int J Infect Dis 2014;29:301-306

26 Assiri A, Al-Tawfiq JA, Al-Rabeeah AA, et al. Epidemiological, demographic, and clinical characteristics of 47 cases of Middle East respiratory syndrome coronavirus disease from Saudi Arabia: a descriptive study. Lancet Infect Dis 2013;13(09):752-761

27 Yang M, Ng MH, Li CK. Thrombocytopenia in patients with severe acute respiratory syndrome (review). Hematology 2005;10(02): 101-105

28 Qin C, Zhou L, Hu Z, et al. Dysregulation of immune response in patients with COVID-19 in Wuhan, China. Clin Infect Dis 2020 (epub ahead of print) . Doi: 10.1093/cid/ciaa248

29 Gao Y, Li T, Han M, et al. Diagnostic utility of clinical laboratory data determinations for patients with the severe COVID-19. J Med Virol 2020 (e-pub ahead of print) . Doi: 10.1002/jmv.25770

30 Oleksowicz L, Mrowiec Z, Zuckerman D, Isaacs R, Dutcher J, Puszkin E. Platelet activation induced by interleukin-6: evidence for a mechanism involving arachidonic acid metabolism. Thromb Haemost 1994;72(02):302-308 